\title{
Causes of variation in crystal morphology in metamorphogenic pyrite deposits of the Cameros Basin (N Spain)
}

\author{
J. ALONSO-AZCÁRATE" ${ }^{*}$, M. RODAS ${ }^{2}$, L. FERNÁNDEZ-DÍAZ $Z^{2}$, S.H. BOTTRELL ${ }^{3}$, \\ J. R. MAS ${ }^{4}$ and S. LÓPEZ-ANDRÉ $S^{2}$ \\ ${ }^{1}$ Facultad de Ciencias del Medio Ambiente, Universidad de Castilla-La Mancha, Toledo, Spain \\ ${ }^{2}$ Departamento de Cristalografía y Mineralogía, Universidad Complutense de Madrid, Madrid, Spain \\ ${ }^{3}$ Department of Earth Sciences, University of Leeds, Leeds, UK \\ ${ }^{4}$ Departamento de Estratigrafía, Universidad Complutense de Madrid, Madrid, Spain
}

The low-grade metasediments of the Cameros Basin, northern Spain, host a number of deposits of spectacular quality pyrite mineralization. These formed during regional metamorphism and the pyrite crystals exhibit a wide range of morphologies. On the basis of pyrite crystal habit, the deposits can be classified into two groups: Group I comprises deposits with cubic, elongated or platy crystals; Group II comprises deposits characterized by pyritohedra and cubo-pyritohedra with striated faces, along with blocky crystals and fine-grained aggregates. Group I deposits are formed in sequences dominated by meandriform fluviatile sediments, while Group II is hosted by deltaic plain and lacustrine metasediments.

Temperature differences between deposits and As content are possible causes of the different pyrite morphologies in the deposits, but no significant variation exists between the two groups for either factor. Comparison with experimentally grown pyrite crystals suggests that Group I deposits have morphologies indicative of lower degrees of pyrite supersaturation than pyrite crystals in Group II deposits. The sedimentary facies hosting Group II deposits provides a greater availability of sedimentary sulphur (pyrite and sulphates). Moreover, reactions involving sulphate during metamorphism may have modified fluid chemistry, which would also act to produce higher degrees of pyrite saturation in fluids derived from the sulphate-rich deltaic plain and lacustrine metasediments hosting the Group II deposits. This hypothesis is confirmed by sulphur isotope data on the pyrites, which show a larger component of ${ }^{34} S$-enriched sulphate-derived sulphur in these deposits. Copyright (C) 2001 John Wiley \& Sons, Ltd.

KEY WORDS pyrite; crystal morphology; sulphur isotopes; supersaturation; sulphur availability; fluid chemistry; Cameros Basin; Spain

\section{INTRODUCTION}

Pyrite crystals can exhibit a wide variety of habits (Goldschmidt 1920). However, most of them are defined by the combination of a reduced number of forms, mainly cubic form a $\{100\}$, octahedral form o $\{111\}$ and pyritohedral form $\mathrm{e}\{210\}$. Experimental synthesis of hydrothermal pyrite crystals shows that temperature and degree of supersaturation are important in determining pyrite morphology (Murowchick and Barnes 1987). However, the controls on pyrite morphology in natural hydrothermal systems are poorly understood. Indeed, the behaviour of sulphur species during metamorphism has received relatively little attention, despite the role of sulphur sourced from sediments and metasediments in the formation of ore deposits (e.g. Sverjensky 1981; Ohmoto 1986; Cortecci et al. 1987; Bottrell and Spiro, 1988).

\footnotetext{
* Correspondence to: J. Alonso-Azcárate, Facultad de Ciencias del Medio Ambiente, Universidad de Castilla-La Mancha, Fabrica de Armas,
} 45004, Toledo, Spain. E-mail: azcarate@amb-to.uclm.es 
The metamorphogenic pyrite deposits in the Cameros Basin, N Spain, exhibit a wide range of pyrite morphologies. In this study we utilize sulphur isotopic data to investigate whether degree of supersaturation actually exerted significant control on pyrite morphology during hydrothermal growth, as experimental work would suggest. We also examine the factors giving rise to variation in sulphide availability and pyrite saturation in fluids in metasediments. Possible effects of temperature and As content on pyrite morphology are also considered.

Murowchick and Barnes (1987) have experimentally studied the effects of temperature and the degree of supersaturation on the morphology of hydrothermally grown pyrite crystals, in the temperature range between 250 and $500^{\circ} \mathrm{C}$. They found that temperatures around $250^{\circ} \mathrm{C}$ and low degrees of supersaturation produce needle-like pyrite crystals. An increase in the degree of supersaturation leads to the development of cubes with perfectly smooth a $\{100\}$ faces and small $o\{111\}$ faces. Higher temperatures (around $450^{\circ} \mathrm{C}$ ) and low degrees of supersaturation produce large striated cubes with small octahedral faces. The combination of high temperature and high supersaturation levels leads to the formation of heavily striated cubes with or without octahedral faces. Finally, crystals grown under the very high supersaturation levels achieved in quenching exhibit morphologies ranging from pyritohedral to blocky crystals to skeletal octahedra and dendrites. Murowchick and Barnes (1987) consider that all the morphologies, except those relating to crystals formed during quenching, are the result of surface-controlled growth. Crystals formed during quenching show a sequence of morphologies (octahedra, skeletal octahedra, dendrites and fine-grained pyrite) that indicates the gradual transition from two-dimensional nucleation-controlled growth (surface-controlled growth) to continuous growth (diffusion-controlled growth).

\section{GEOLOGICAL BACKGROUND}

The Cameros Basin is located in the north-westernmost part of the Iberian Range (Figure 1) and represents the most important accumulation of sediments within the Mesozoic basins of the mountain chain. The sedimentary sequence in the Cameros Basin comprises sediments of continental origin (alluvial and lacustrine systems) with very rare marine incursions (Alonso and Mas 1993). The basin is unique within the context of the Iberian Range due to its high subsidence and sedimentation rates, which resulted in a very thick (up to $9000 \mathrm{~m}$ ) Tithonian to Early Albian sedimentary series. It is also the only basin in the Iberian Range in which part of the basin fill has been affected by metamorphism. This metamorphism has been considered as hydrothermal by different authors (Casquet et al. 1992; Barrenechea et al. 1995; Alonso-Azcárate et al. 1995) with a maximum T and P of approximately $350^{\circ} \mathrm{C}$ and $1 \mathrm{kbar}$ respectively.

The sediments which host the mineralization were deposited in two contrasting sedimentary environments. Sediments hosting the Arroyo Canadillas and Ambasaguas deposits were deposited in deltaic plains with frequent lacustrine episodes and are characterized by the presence of relatively high contents of organic matter and reactive Fe minerals. In these lacustrine facies the presence of sedimentary pyrite is common, as well as sedimentary sulphates (Alonso-Azcárate et al. 1999a). In contrast, sediments hosting the Navajún, Valdeperillos, Valdenegrillos, Valoria and Munilla deposits were formed in meandering fluvial systems characterized by low contents of sedimentary pyrite and no sulphate minerals.

Within the Cameros Basin, the pyrite deposits are concentrated in a small geographical area in the eastern sector (Figure 1) and formed under very similar geological conditions. Pyrite crystals from the deposits are known worldwide for their size and quality and, despite the proximity and similarity of the deposits in other respects, the whole range of pyrite crystal morphologies can be found amongst the deposits. Recent studies of the deposits (Alonso-Azcárate 1997; Alonso-Azcárate et al. 1999a) have shown that they formed close to the peak of metamorphism and resulted from the introduction of locally derived sulphidic metamorphic fluids into beds containing Fe-rich chlorite. The resulting reaction released Fe from chlorite to form pyrite, leaving an Fe-poor chloritic residue.

The metamorphic conditions reached by the different deposits have been estimated on the basis of the crystallochemical parameters (illite and chlorite crystallinity indices) and mineralogical assemblages of the matrix phyllosilicates in each deposit (Alonso-Azcárate et al. 1999a). The sediments from Ambasaguas, A. Canadillas and 


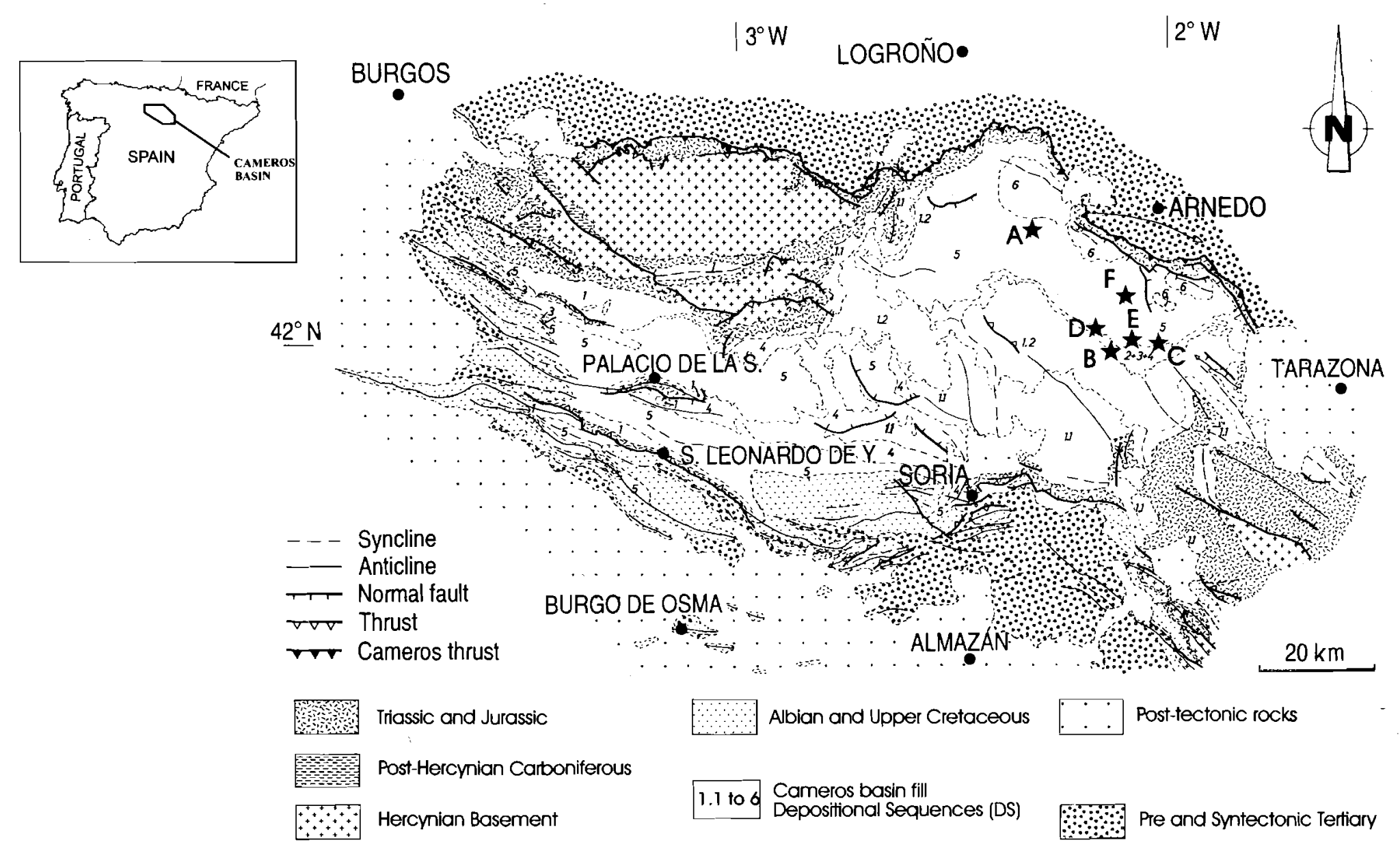

Figure 1. Location of the Cameros Basin in northern Spain and geological map of the Cameros Basin, including the location of the different pyrite deposits. A, Munilla; B, Valdenegrillos; C, Navajún; D, Valoria; E, Valdeperillos; F, Ambasaguas-A. Canadillas (modified from Guimerá et al. 1995, reproduced by permission of the Geological Society of London). 
Munilla mineralizations are located in the anchizone field. The Navajún, Valdenegrillos and Valoria deposits are transitional between anchizone and epizone and the Valdeperillos mineralization is in the beginning of the epizone field.

\section{MATERIALS AND METHODS}

Seven pyrite deposits were selected for study on the basis of the morphological characteristics of their crystals (Figure 1). Since the pyrite crystals are hosted mainly in pelites and occasionally in marls, extraction of the crystals from the host rock is simple. Samples were carefully separated from the host rock with the help of a dental drill. Where iron oxide coatings were found, they were removed by washing with oxalic acid or with $\mathrm{HCl}$ when the coatings were thicker. Between 75 and 100 pyrite crystals were examined from each deposit to cover the whole range of habits represented in each. Pyrite polished slabs were etched with $\mathrm{HNO}_{3}$ to detect internal morphologies.

In some crystals with morphologies representative of each deposit, $S$ isotope analyses and As content determinations were performed on bulk pyrite crystals at the Earth Science Department, Leeds University. Sulphur isotope ratios $\left({ }^{34} \mathrm{~S} /{ }^{32} \mathrm{~S}\right)$ were measured on sulphur dioxide gas prepared by oxidation of pyrite with cuprous oxide (Robinson and Kusakabe 1975) using a VG SIRA 10 mass spectrometer. The results are given in conventional $\delta^{34} \mathrm{~S}$ notation as per mil (\%) variations relative to the Cañon Diablo Troilite (CDT) standard and have accuracy and precision of $c .0 .2 \%$. The induction coupled plasma atomic emission spectroscopy (ICP-AES) analyses were done in the Atomic Spectrometry Centre of Complutense University, Madrid. The As content was measured by ICPAES, after checking by reflected-light microscopy that there were no other sulphide minerals present. Samples for ICP-AES were prepared by dissolution of the powdered crystals at pressure with $\mathrm{HF} / \mathrm{HClO}_{4} / \mathrm{HNO}_{3}$. The precision is better than $\pm 2 \%$.

\section{RESULTS}

\subsection{Crystal morphology}

In order to describe the morphology of the crystals found in these deposits, the following categories can be established.

Class A: crystals with morphology defined by cube faces a 100$\}$ (Figure $2 \mathrm{~A}-\mathrm{C}$ ). This class includes three different habits depending on the relative development of the three pairs of cube faces. When one pair of these faces shows a smaller development, the crystal is elongated along one axis, with a length: width ratio around 7:1 (Figure $2 \mathrm{~A}$ ); the length of the longest edge ranges from millimetres to $5 \mathrm{~cm}$. When two pairs of faces show a smaller relative development, crystals have a platy habit (Figure 2B); the length of the longest edge also ranges from millimetres to $5 \mathrm{~cm}$. Both habits are well represented in the Valdeperillos deposit. They also appear in Navajún, Valdenegrillos, Valoria and Munilla, although with a lower frequency. The third habit corresponds to an equal development of all cube faces a $\{100\}$. The morphology of the crystal is a cube (Figure $2 \mathrm{C}$ ). In this case the longest edge can range from millimetres to $19 \mathrm{~cm}$. This habit is the most common one in most deposits. It is especially well represented in Navajún, Valdenegrillos, Valoria and Munilla.

The surfaces of all crystals included in this class are free of striations. Moreover, crystals corresponding to the three habits lay within the deposits in a random way without any preferential orientation. The whole range of intermediate morphologies has been observed.

Class B: crystals with cubo-octahedral morphology (Figure 2D). This habit is defined by the forms a $\{100\}$ and $o\{111\}$. Crystals with this morphology are limited to the Navajún deposit. They occur in a small lens, grading laterally into cubes. Most of these crystals have a hopper appearance, with both faces $\{100\}$ and $\{111\}$ showing large steps and the centre slightly depressed. The steps are defined by elongated pseudohexagonal layers limited by $\langle 100\rangle,\langle 110\rangle$ and $\langle\overline{1} 10\rangle$ edges. A detail of these layers can be observed in Figure 2D. Normally, $\{100\}$ is the most extended form. However, all intermediate morphologies between cube and cubo-octahedron have been observed. The size of these crystals ranges from millimetres to $5 \mathrm{~cm}$. 


\section{A}

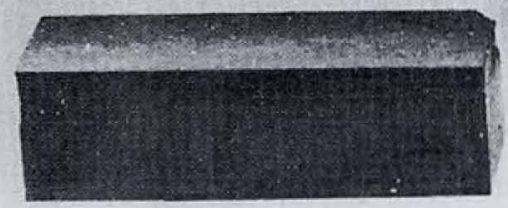

C

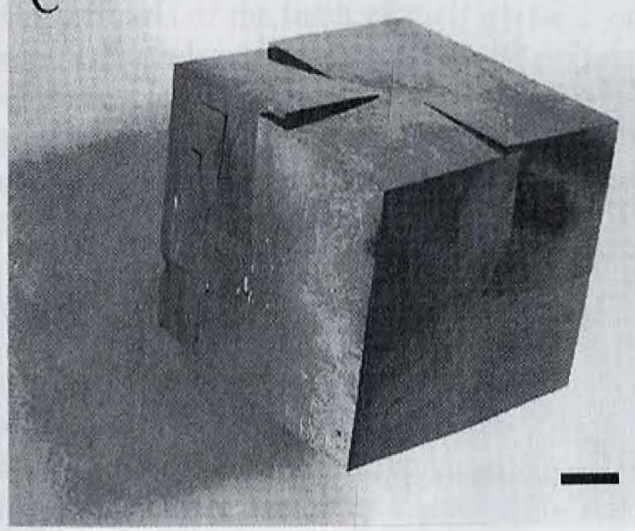

E

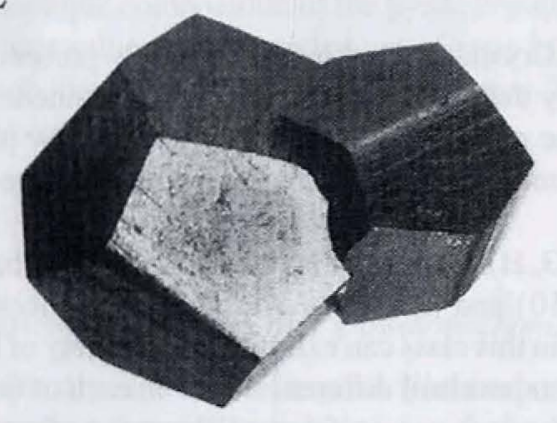

Figure 2. Characteristic pyrite habits in the Cameros Basin. (A) Elongated crystal from Valdeperillos deposit. (B) Platy crystal from Navajún deposit. (C) Cubic crystal from Navajún deposit. (D) Cubo-octahedral crystal from Navajún deposit in which the elongated pseudohexagonal growth layers determining a hopper morphology in its faces can be observed. (E) Pyritohedral crystals from Ambasaguas deposit. (F) Heavily striated modified pyritohedral crystal from Ambasaguas deposit. (G) Cluster of heavily striated cubo-pyritohedral crystals from Ambasaguas deposit. (H) Cubic crystal modified by pyritohedral faces from Ambasaguas deposit. (I) Blocky crystal from A Canadillas deposit. Scale bar: 1 cm. 

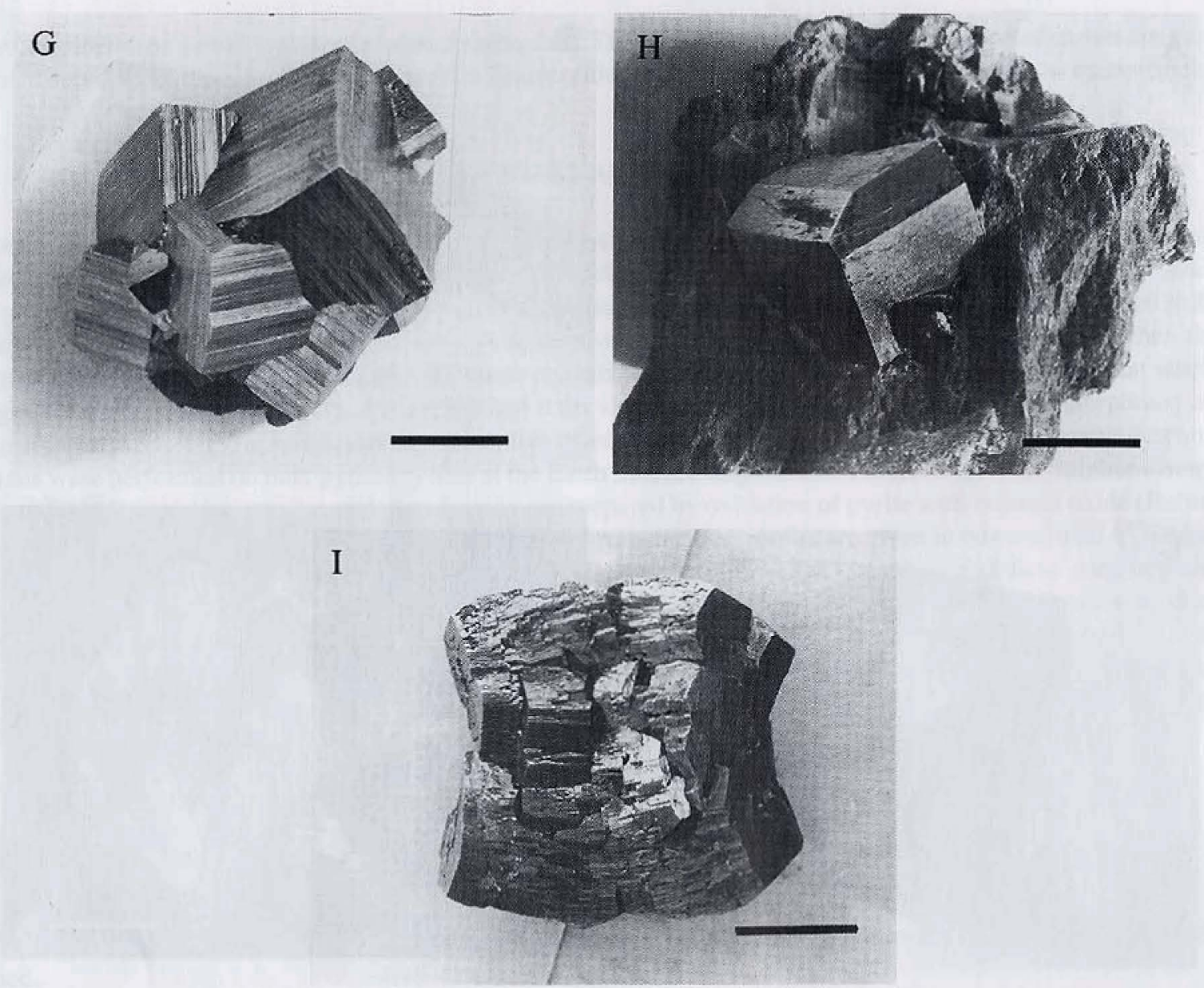

Figure 2. Continued.

Class $C$ : crystals with pyritohedral morphology (Figure 2E, F). Crystals with this habit are only present in the Ambasaguas and Arroyo Canadillas deposits. This habit is normally defined by the form $\{210\}$; pyritohedra characterized by the forms $\{310\},\{410\}$, and $\{320\}$ also exist but are rare. The surface of the faces show positive striations (Endo and Sunagawa 1973); the larger the crystals, the more heavily striated they are. The size of the pyritohedra ranges from millimetres to $10 \mathrm{~cm}$.

Class D: crystals with cubo-pyritohedral morphology (Figure $2 \mathrm{G}, \mathrm{H}$ ). This habit is defined by the combination of cube faces a $\{100\}$ and the pyritohedron faces $\{210\},\{310\},\{410\}$ and $\{320\}$. As a result of differences in the relative development of these different forms, the crystals included in this class can exhibit a wide variety of habits. The combination of cube and two or more pyritohedra appears as two bevels of different slopes on each of the cube edges. The surfaces are normally heavily striated. The size of the crystals ranges from millimetres to $9 \mathrm{~cm}$. Irregular aggregates formed by more than 100 individuals are frequently found. This type of crystal is common in the Ambasaguas and A. Canadillas deposits.

Class E: blocky crystals with striated poorly defined faces (Figure 2I). This morphology is common in the A. Canadillas deposit and rare in the Ambasaguas deposit. The size of the crystals ranges from millimetres to $4 \mathrm{~cm}$.

All intermediate morphologies between cubes, pyritohedra and blocky crystals have been observed. In the Ambasaguas and A. Canadillas deposits it is also possible to find very fine-grained pyrite aggregates without any distinctive crystal shape. When polished slabs have been etched, internal growth zones can be 
Table 1. As content, $S$ isotopic composition and group classification of deposits for selected crystals of each class of pyrite habit

\begin{tabular}{lllr}
\hline Habit & \multicolumn{1}{c}{ As $(\mathrm{ppm})$} & \multicolumn{1}{c}{$\delta^{34} \mathrm{~S}(\%)$} & Deposit \\
\hline Blocky crystals & 125.3 & $7.7,8.6,9.6,7.8,8.1$ & \\
Pyritohedron & 124.6 & $1.1,6.5,7.4,7.1,0.8$ & Group II \\
Cubo-pyritohedron & $128.9,2482$ & $0.2,5.8,6.1,6.2,5.6,5.9,6.1$ & \\
\hline Cubo-octahedron & 116.1 & $-0.5,-1.0,-0.7,-0.9$ & \\
Cube & $124.9,138.2,131.0,132.2,128.2,129.3$ & $-4.4,-4.3,-4.9,-5.9,-5.9,-7.3$ & Group I \\
Platy crystal & $132.5,114.4$ & $3.1,1.9,-7.0,-10.5$ & \\
Elongated crystal & $127.0,127.4$ & $-7.6,3.0,-5.8,-6.3,-2.6$ & \\
\hline
\end{tabular}

distinguished by lineations marked by inclusions, by different inclusion densities, or by variations in the intensity of the etching. The morphologies of the internal growth zones always reproduce the external habit of the crystal, with internal growth zones parallel to the crystal edges. This reflects a constancy in the growth mechanism, showing that the same mechanism has dominated the growth process throughout the growth of each crystal.

On the basis of the habit of their pyrite crystals, the deposits studied can be classified into two groups. One (Group I) includes those deposits where pyrite has crystallized as cubic crystals with flat faces and, more rarely, as elongated and/or platy crystals. This group comprises the Navajún, Valdeperillos, Valdenegrillos, Valoria and Munilla deposits. Group II comprises those deposits where pyrite crystals have grown as pyritohedra and cubopyritohedra with rough striated faces or as blocky crystals and fine-grained aggregates. This group comprises the Ambasaguas and A. Canadillas deposits.

\subsection{Analytical data}

Table 1 summarizes the As content and $\delta^{34} \mathrm{~S}$ values corresponding to the different morphologies in all the deposits studied. As content is generally low and the range of variation is very narrow except for a cubo-pyritohedral crystal in the A. Canadillas deposit with a high As content, probably due to the presence of an As-bearing inclusion in the pyrite crystal. The amount of $S$ present in such a sulph-arsenide mineral inclusion would have no effect on the pyrite $\delta^{34} S$ value of this sample. Variation in As content does not show any correlation with morphological variations in the pyrite, nor are there consistent differences between individual pyrite deposits.

The isotopic composition of the pyrite crystals varies over a wide range from -10 to $8 \%$ (Figure 3). In general, the lightest values are associated with Group I (cubic, platy and elongated crystals) and heavier values with Group $\mathrm{II}$, though there is some overlap of the groups. There is no systematic variation in $\delta^{34} \mathrm{~S}$ between the morphological sub-divisions of groups I and II.

\section{DISCUSSION}

\subsection{Pyrite morphologies and growth mechanisms}

The pyrite deposits of the Cameros Basin represent an extraordinary natural example of mineralization where the whole range of pyrite morphologies can be found. Two principal groups of deposits with contrasting pyrite morphologies can be distinguished in the Cameros Basin. In the first group (Navajún, Valdeperillos, Valdenegrillos, Valoria and Munilla), pyrite crystals have grown as cubes with smooth faces and, less commonly, as elongated or platy crystals. These morphologies indicate that crystal growth was surface-controlled (Murowchick and Barnes 1987). The elongated and platy habits result from spiral growth (Burton et al. 1951), with active screw dislocation outcropping on one pair (elongated crystals) or two pairs (platy crystals) of opposite $\{100\}$ faces (Sunagawa 1987), whereas no dislocations are effective as growth sites on the other $\{100\}$ faces. Elongated and platy pyrite crystals are randomly oriented within the deposit, thus the anisotropy of the morphologies cannot be related to systematic 


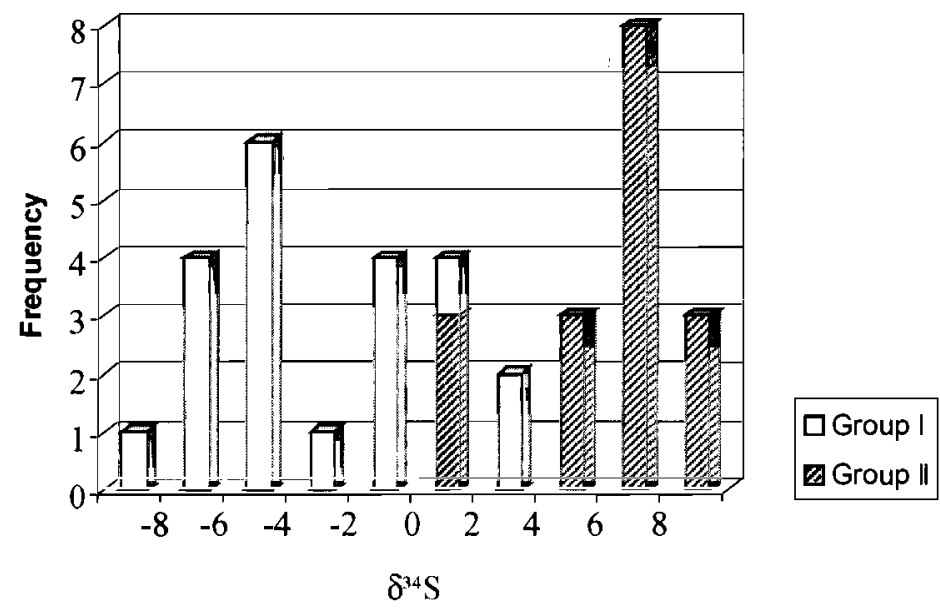

Figure 3. Frequency distribution of $\delta^{34} \mathrm{~S}$ values from Table 1 .

anisotropy in the growth medium, solution flows, stress field, etc. Cubes with smooth flat faces could result from either screw dislocation-controlled growth, with an even distribution of screw dislocations on $\{100\}$ faces, or twodimensional nucleation-controlled growth (Stranski 1928; Kossel 1930) with a low rate of nucleation. As mentioned in the previous section, the Navajún deposit also includes pyrite crystals with cubo-octahedron morphology. These crystals result from the growth of $\{100\}$ faces by two-dimensional nucleation with a higher rate of nucleation. The growth layers are bounded by $\langle 100\rangle$ and $\langle 110\rangle$ edges (Figure 2D) and their piling up leads to the development of $\{111\}$ faces. When a crystal grows from a solution phase, the supersaturation over the crystal surface is not homogeneous, but higher near the periphery and lower at the centre of the face (Berg 1938). Thus, the probability of two-dimensional nucleation is higher at the edges. Consequently, growth layers originate at the edges and, when the two-dimensional nucleation mechanism controls the crystal growth process, hopper crystals result (Figure 2D).

The second group includes the Ambasaguas and A. Canadillas deposits, where pyrite crystals exhibit morphologies that range from pyritohedra and cubo-pyritohedra, with faces showing a variable degree of striation, to blocky crystals and very fine-grained pyrite aggregates. These morphologies have to be interpreted as produced by growth under conditions poised between the surface-controlled regime and the diffusion-controlled regime. Cube-pyritohedra and pyritohedra result from two-dimensional nucleation growth, with rates of nucleation high enough to produce piling-up of spreading layers (Sunagawa 1987). Striation also originates from the piling-up process (Endo and Sunagawa 1973). On the other hand, the formation of blocky crystals and fine-grained pyrite aggregates can be explained by continuous growth. Blocky crystals are composed by a mosaic of subindividuals and represent the initial stage of crystal splitting during growth. Under this diffusion-controlled regime, the concentration of reactants increases away from the surface of the crystal. Thus, the corners of the crystal tend to protrude into a higher supersaturation region and the growth of the protrusion will be promoted rather than the growth of a flat surface, thereby generating blocky crystals (Figure 2I).

\subsection{Controls on pyrite morphology}

Following Murowchick and Barnes (1987), it is possible to interpret the morphological differences between the two groups of deposits as the result of differences in physicochemical conditions (mainly, supersaturation and/or temperature) existing in each deposit during formation. Increasing growth temperature or supersaturation would lead to a change from surface-controlled growth to diffusion-controlled growth. This change in the growth mechanism would in turn be expressed as different crystals morphologies. Figure 4 shows the different pyrite habits and their possible relationship with crystal growth mechanism and degree of supersaturation. 


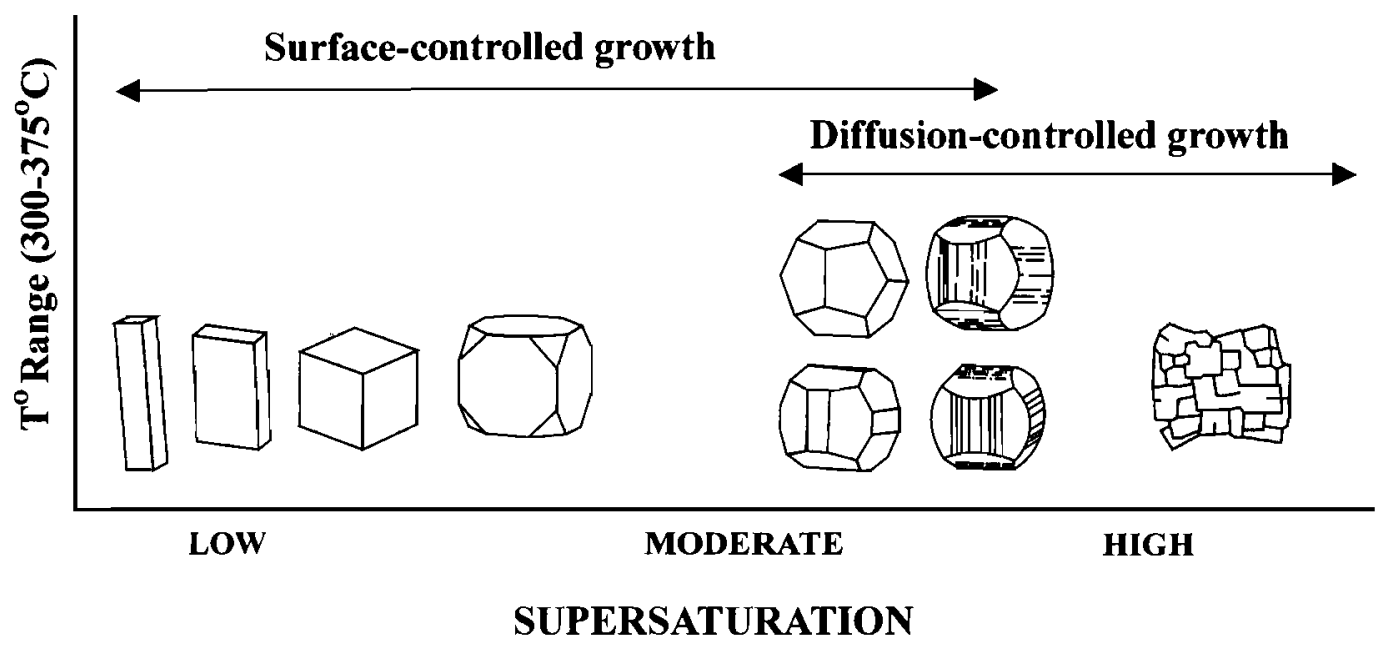

Figure 4. Relationships between pyrite habits, degree of supersaturation and crystal growth mechanism.

As detailed above, these deposits originated during anchizone-epizone hydrothermal metamorphism. There is little variation in metamorphic conditions prevalent at the different deposits and thus there could not have been important differences in temperature between them (Alonso-Azcárate et al. 1999a, 1999b). Moreover, the second group of deposits (Ambasaguas and A. Canadillas), which included those morphologies originated by continuous growth, is in the area where the metamorphism, and so the temperature, was lower, only reaching the anchizone. Consequently, it has to be concluded that temperature has not been an important factor in directly controlling the growth mechanism.

The presence of impurities in the growth medium is another factor that has an influence on the roughness of a crystal surface. Several authors (Hayashida and Muta 1952; Sunagawa and Takahashi 1955) have discussed the role of As in the development of the o\{111\} form, concluding that the presence of this element in the growth medium promotes the appearance of $\{111\}$ faces. However, they note that this effect can easily be overcome under the influence of other factors. Pyrite crystals with \{111\} faces are only present in the Navajún deposit; the cubo-octahedron from Navajún shows the lowest As content (Table 1). Therefore, high As contents would appear not to be implicated in $\{111\}$ development in Cameros Basin pyrite crystals.

Therefore, the degree of supersaturation would appear to be the factor primarily responsible for the morphological differences observable between the two groups of deposits in the Cameros Basin. Degree of saturation would have to be higher for the A. Canadillas and Ambasaguas deposits than for the others to account for their pyrite morphology. We now investigate what factors may have controlled this difference.

\subsection{Factors controlling pyrite supersaturation}

The overall precipitation mechanism for hydrothermal pyrite can be summarized by these two simple reactions:

$$
\begin{aligned}
& \mathrm{Fe}^{2+}+2 \mathrm{HS}^{-} \Rightarrow \mathrm{FeS}_{2}+\mathrm{H}_{2} \\
& \mathrm{Fe}^{2+}+2 \mathrm{H}_{2} \mathrm{~S} \Rightarrow \mathrm{FeS}_{2}+2 \mathrm{H}^{+}+\mathrm{H}_{2}
\end{aligned}
$$

For these reactions the equilibrium constants are:

$$
k_{1}=\frac{\mathrm{aFe}^{2+} \cdot\left(\mathrm{aHS}^{-}\right)^{2}}{\mathrm{aFeS}_{2} \cdot \mathrm{fH}_{2}}
$$




$$
k_{2}=\frac{\mathrm{aFe}^{2+} \cdot\left(\mathrm{fH}_{2} \mathrm{~S}\right)^{2}}{\mathrm{aFeS}_{2} \cdot\left(\mathrm{aH}^{+}\right)^{2} \cdot \mathrm{fH}_{2}}
$$

for Reactions 1 and 2 respectively.

Therefore the supersaturation in pyrite of a system is dependent on the activity of $\mathrm{Fe}^{2+}$ and $\mathrm{HS}^{-}$, the fugacity of $\mathrm{H}_{2} \mathrm{~S}$ and both redox $\left(\mathrm{fH}_{2}\right)$ and $\mathrm{pH}\left(\mathrm{aH}^{+}\right)$conditions. The predominance of Reaction 1 or 2 is controlled by sulphur speciation:

$$
\mathrm{HS}^{-}+\mathrm{H}^{+} \Rightarrow \mathrm{H}_{2} \mathrm{~S}
$$

which is also $\mathrm{pH}$ dependent.

The formation of pyrite deposits occurred in metapelite units with elevated contents of sedimentary chlorite (Alonso-Azcárate et al. 1995; Alonso-Azcárate 1997). The availability of $\mathrm{Fe}\left(\mathrm{aFe}^{2+}\right.$ in $k_{1}$ and $\left.k_{2}\right)$ was thus controlled by the same factor - chlorite breakdown at the locus of pyrite formation - and thus similar at all deposits.

The A. Canadillas and Ambasaguas deposits are hosted by lacustrine deltaic plain deposits. These sediments have relatively high initial sedimentary pyrite contents and sedimentary sulphate is common compared to the meandriform fluviatile sediments which host the other deposits (Alonso-Azcárate 1997). Sedimentary pyrite provides one source of reduced sulphur to the deposits by release of sulphur via thermal breakdown of pyrite during metamorphism (Alonso-Azcárate et al. 1999a).

The presence of abundant sulphate will have profound effects on fluid chemistry during metamorphism. Reactions such as:

$$
\begin{aligned}
& \mathrm{SO}_{4}^{2-}+\mathrm{H}^{+}+4 \mathrm{H}_{2} \Rightarrow 4 \mathrm{H}_{2} \mathrm{O}+\mathrm{HS}^{-} \\
& \mathrm{SO}_{4}^{2-}+2 \mathrm{H}^{+}+4 \mathrm{H}_{2} \Rightarrow 4 \mathrm{H}_{2} \mathrm{O}+\mathrm{H}_{2} \mathrm{~S}
\end{aligned}
$$

will influence both redox $\left(\mathrm{fH}_{2}\right)$ and $\mathrm{pH}$, as well as generating reduced sulphur. Unless oxide-silicate $\mathrm{pH}$ and redox buffers in these rocks dominate, fluids generated in sulphate-rich lithologies will have lower $\mathrm{fH}_{2}, \mathrm{lower}_{\mathrm{aH}}^{+}$and higher aHS ${ }^{-}$or $\mathrm{fH}_{2} \mathrm{~S}$. The effect of such fluids on pyrite precipitation Reactions 1 and 2 will be to increase the degree of pyrite saturation (see $k_{1}$ and $k_{2}$ above).

Thus we hypothesize that metamorphic fluids in the sulphate-bearing lacustrine sediments hosting the A. Canadillas and Ambasaguas would be expected to have higher degrees of pyrite saturation and that this contributed to the formation of the different pyrite morphologies found in these deposits. This hypothesis can be tested using the isotopic compositions of the pyrites. Reactions 4 and 5 supply reduced sulphur to the metamorphic fluid by thermochemical reduction of a sedimentary sulphate source, which is relatively ${ }^{34} \mathrm{~S}$-enriched (Alonso-Azcárate et al. 1999a). Reactions involving metamorphic reduction of sulphate minerals have been described in these low-grade metasediments (Alonso-Azcárate et al. 2001). Thermochemical reduction of sulphate does not produce isotopic fractionation between sulphate reactants and sulphide products (Krouse 1977; Machel et al. 1995). The sedimentary sulphates are enriched in ${ }^{34} \mathrm{~S}$ compared to sedimentary sulphide (AlonsoAzcárate et al. 1999a), so if Reactions 4 and 5 have influenced the metamorphic fluid chemistry as suggested above, then as a consequence pyrite at the A. Canadillas and Ambasaguas deposits should be enriched in ${ }^{34} \mathrm{~S}$ relative to the others. The crystals with high supersaturation morphologies from the Group II A. Canadillas and Ambasaguas are indeed enriched in ${ }^{34} \mathrm{~S}$ compared to the other deposits with low supersaturation morphologies (Figure 3). Even though there is some overlap in the data, they form a population which is significantly different from the other deposits at the $99.9 \%$ confidence level. From this we conclude that increased sulphur availability and changes in fluid redox and $\mathrm{pH}$ as a result of Reactions 4 and 5 were dominant in controlling pyrite supersaturation. 


\section{SYNTHESIS AND WIDER IMPLICATIONS}

Pyrite crystals in metamorphogenic deposits from the Cameros Basin exhibit a wide variety of morphologies, and crystal morphology is shown to act as a proxy for the degree of supersaturation reached by the fluids in each deposit during mineralization. Iron availability was controlled by the same chlorite breakdown reaction in each case, hence the degree of supersaturation represents the chemistry of sulphidic fluid generated in the different sedimentary facies local to each deposit. Higher supersaturation (Group II) deposits are hosted by sediments which have higher availability of sedimentary sulphur (pyrite and sulphates) than Group I. Moreover, metamorphic reactions involving sulphate produced more oxidized, higher $\mathrm{pH}$ fluids with higher reduced sulphur concentrations which yielded a higher degree of pyrite saturation. This is reflected in a larger component of ${ }^{34} \mathrm{~S}$-enriched sulphate-derived sulphur in pyrites of the Group II deposits which exhibit morphologies characteristic of higher degrees of supersaturation.

We have demonstrated that, during low-grade metamorphism of sedimentary sequences, significant differences in sulphur chemistry can be developed between different sedimentary units as a result of their differing primary sedimentary facies. Sulphur chemistry and sulphide mineral saturation are essentially locally controlled. Some lithologies would therefore provide sulphide for ore formation far more readily than others and would be able to act as preferential loci of ore formation. In metamorphic settings, reduction of sulphate minerals provides a mechanism for locally enhanced sulphide production and availability. Previously, Schwarcz and Burnie (1973) have suggested that the primary control on sulphide $\delta^{34} \mathrm{~S}$ in ore deposits in sedimentary rocks, even where metamorphosed, was degree of open system (producing light $\delta^{34} \mathrm{~S}$ values) behaviour during diagenetic bacterial sulphate reduction. We would urge caution in such an interpretation for sulphide deposits in metamorphic terrains (cf. Ohmoto 1986) since reduction of evaporite sulphate during metamorphism may constitute a source of isotopically heavy sulphur.

\section{ACKNOWLEDGEMENTS}

This paper was supported by the research projects PR 179/91-3469 from Universidad Complutense of Madrid and PB94-0054 from DGICYT. We thank Jose Luis Gonzalez, Maribel Benito, Paco Piña, Roberto Parra and Miguel Romera for the photographic work. Critical reviews by A. Boyce and T. Wagner helped greatly to improve the manuscript. I. Somerville and G. Rowbotham are thanked for editorial handling.

\section{REFERENCES}

Alonso A, Mas JR. 1993. Control tectónico e influencia del eustatismo en la sedimentación del Cretácico inferior de la Cuenca de Los Cameros. España. Cuadernos de Geología Ibérica 17: 285-310.

Alonso-Azcárate J. 1997. Evolución de los filosilicatos y génesis de los yacimientos de pirita en la cuenca de Cameros: su relación con las facies sedimentarias y el metamorfismo. Ph D thesis, Universidad Complutense de Madrid.

Alonso-Azcárate J, Barrenechea JF, Rodas M, Mas JR. 1995. Comparative study of the transition between very low-grade and low-grade metamorphism in siliciclastic and carbonate sediments: Early Cretaceous, Cameros Basin (Northern Spain). Clay Minerals 30: $407-419$.

Alonso-Azcárate J, Rodas M, Bottrell SH, Raiswell R, Velasco F, Mas JR. 1999a. The pyrite deposits of the Cameros Basin, Spain: evidence for channelling of peak metarnorphic fluid flow through sandstone aquifers. Journal of Metamorphic Geology 17: 339-348.

Alonso-Azcárate J, Boyce AJ, Bottrell SH, MacAulay C, Rodas M, Fallick AE, Mas JR. 1999b. Development and use of in situ laser sulfur isotope analyses for pyrite-anhydrite geothermometry: an example from the pyrite deposits of the Cameros Basin, NE Spain. Geochimica et Cosmochimica Acta 63: 509-513.

Alonso-Azcárate J, Bottrell SH, Tritlla J. 2001. Sulfur redox reactions and formation of native sulfur veins during low grade metamorphism of gypsum evaporites, Cameros Basin (NE Spain). Chemical Geology 174: 389-402.

Barrenechea JF, Rodas M, Mas JR. 1995. Clay mineral variation associated to diagenesis and low grade metamorphism of early Cretaceous sediments in the Cameros basin, Spain. Clay Minerals 30: 89-103.

Berg B. 1938. Crystal growth from solutions. Proceedings of the Geological Society of London A168: 79-95.

Bottrell SH, Spiro B. 1988. A stable isotope study of black shale-hosted gold mineralization in the Dolgellau Gold Belt, north Wales. Journal of the Geological Society of London 145: 941-949.

Burton WK, Cabrera N, Frank FC. 1951. The growth of crystals and equilibrium structures of their surfaces. Philosophical Transactions of the Royal Society of London 243: 299-358. 
Casquet C, Galindo C, González Casado JM, Alonso A, Mas R, Rodas M, García E, Bartenechea JF. 1992. El metamorfismo en la Cuenca de los Cameros. Geocronología e implicaciones tectónicas. Geogaceta 11: 22-25.

Cortecci G, Reyes E, Leone G, Turi B. 1987. Sulphur, oxygen, carbon and strontium isotope geochemistry of the Sarrabus-Gerrei mining district, southeastem Sardinia, Italy. Economic Geology 82: 1592-1610.

Endo Y, Sunagawa I. 1973. Positive and negative striations in pyrite. American Mineralogist 58: 930-935.

Goldschmidt V. 1920. Atlas der Kristallformen, Bd. 6, Markasit-Pyrit. Carl Winters Universitätbuchhandlung: Heidelburg; p.179-208, plates 101-144.

Guimerá J, Alonso A, Mas JR. 1995. Inversion of an extensional-ramp basin by a newly formed thrust: the Cameros basin (N. Spain). In Basin Inversion. Buchanan JG, Buchanan PG (eds). Geological Society of London, Special Publication 88: 433-453.

Hayashida S, Muta K. 1952. Relation of trace-element content and crystal form in pyrite. Journal of the Mining Institute of Kyushu 20: 233-238.

Kossel W. 1930. Uber Kristallwachstrum. Naturwiss 18: 901-910.

Krouse HR. 1977. Sulfur isotope studies and their role in petroleum exploration. Joumal of Geochemical Exploration 7: 189-211.

Machel HG, Krouse HR, Sassen R. 1995. Products and distinguishing criteria of bacterial and thermochemical sulfate reduction. Applied Geochemistry 10: $373-389$.

Murowchick JB, Barnes HL. 1987. Effects of temperature and degree of supersaturation on pyrite morphology. American Mineralogist 72: 1241-1250.

Ohmoto H. 1986. Stable isotope geochemistry of ore deposits. In Stable Isotopes in High Temperature Geological Processes, Valley JW, Taylor HP, O'Neil JR. (eds). Reviews in Mineralogy 16, Mineralogical Society of America: Washington DC; $491-559$.

Robinson BW, Kusakabe M. 1975. Quantitative preparation of sulfur dioxide, for ${ }^{34} \mathrm{~S} /{ }^{32} \mathrm{~S}$ analyses, from sulfides by combustion with cuprous oxide. Analytical Chemistry 47: 1179-1181.

Schwarcz HP, Burnie SW. 1973. Influence of sedimentary environments on sulfur isotope ratios in clastic rocks: a review. Mineralium Deposita 8: $264-277$.

Stranski IN. 1928. The theory of crystal growth. Zeitschrift für Physikalische Chemie 136: 259-278.

Sunagawa I. 1987. Morphology of minerals. In Morphology of Crystals, Sunagawa I (ed.). Terrapub: Tokyo; 509-587.

Sunagawa I, Takahashi K. 1955. Preliminary report on the relation between the o(111) face of pyrite crystals and its minor contents of arsenic. Geological Society of Japan Bulletin 6: 1-10.

Sverjensky DA. 1981. The origin of a Mississippi Valley-type deposit in the Viburnum Trend, southeast Missouri. Economic Geology 76: 18481872. 